\title{
Highway Reclamation Using Native Grass Sod for Sediment Control and Aesthetic Enhancement
}

\author{
Jing Gong \\ Research Institute of Architecture \\ Wuhan Polytechnic University \\ Wuhan, China \\ email:316264123@qq.com
}

\author{
Zhipeng Li \\ Research Institute of Architecture \\ Wuhan Polytechnic University \\ Wuhan, China \\ email: 515787925@qq.com
}

\author{
Ming Huang \\ College of Urban Construction \\ Wuchang University of Technology \\ Wuhan,China \\ email: $\underline{815686723 @ q q . c o m}$
}

Ye Li

Research Institute of Architecture

Wuhan Polytechnic University

Wuhan, China

email: 458232864@qq.com

\begin{abstract}
This research project will attempt to combine the quick establishment and soil reinforcing properties of sod with the long-term benefits of using native plants. It builds on research by Dollhopf and other scientists in the Land Resources and Environmental Services Department and the Plant Sciences and Pathology Department at MSU. Researchers worked with Bitterroot Turf Farm in Corvallis, Montana to develop, propagate, and test native grass sod for the Montana Department of Transportation. "This foundation research helped us develop methodologies and cost information that we can directly apply in California," said Dollhopf; "We are using our experience selecting, growing, harvesting, and transporting native grass sod in Montana to develop appropriate sods for California.
\end{abstract}

Keywords-native grass,sediment control;species abundance;canopy coverage, weed emergence

\section{INTRODUCTION}

Native grass sod has the potential to provide immediate sediment control and permanent stabilization on disturbed land along highways. This experiment began with an investigation of the basic characteristics of three native grass sods produced by three different commercial farms. While successfully grown in relative small, controlled experimental settings, it was critical to establish the characteristics of these sods when produced at the larger scale necessary for their practical use on highway projects. The commercially grown sods were evaluated with respect to species abundance, canopy coverage, and weed emergence. Based on the results of this investigation, two of these native grass sods were subsequently transplanted to the field test site, where their performance was evaluated over a 20 month period relative to a control section that used Caltrans standard hydroseeding practice.

\section{Propagation of Native Grass Sod For the CALIFORNIA GRASSLAND ECOREGION}

Native grass sod was propagated at three different farms in the California Grassland Ecoregion during February 2005 to May 2008. Native grass sods were named as follows:

- $\quad$ MSU Native Grass Sod - Sierra

- MSU Native Grass Sod - Hedgerow

- $\quad$ MSU Native Grass Sod - Delta

\section{A. Propagation of MSU Native Grass Sod-Sierra}

Grass species selection criteria included root length, root distribution traits, phenology of growth at all life stages, and growth habit. Sierra Sod and Supply, Davis, California, was contracted to propagate the sod. Because of heavy precipitation and work schedule conflicts at the farm, the planting date was April 1, 2005. It was hoped the native grass species mix selected would form a sufficiently dense shallow root mat to enable routine sod cutting and rolling procedures during transplanting.

On April 29, 2005, the seeded area was evaluated by randomly dropping a $0.1 \mathrm{~m} 2$ Daubenmire frame 16 times on the sod plot. Density ranged from 190 to 3590 tillers $/ \mathrm{m} 2$ with an average of 1528 tillers $/ \mathrm{m} 2$. Percent cover averaged $10.2 \%$ and ranged from 1 to $25 \%$. There were areas of an annual grass weed and dense broadleaf weeds that were beginning to compete with seeded native grass.

The seeded area was evaluated a second time on September 2, 2005. All native grasses were dormant, and weeds dominated the plot. A $0.1 \mathrm{~m} 2$ Daubenmire frame was randomly dropped ten times over the seeded area. The 
percent cover of weedy species was $100 \%$ in half of the observed frames.

It was determined that a standard level of care pertaining to weed control associated with native grass sod propagation was absent. Therefore, work was terminated at the farm.

\section{B. Propagation of MSU Native Grass Sod-Hedgerow}

A new native grass sod was designed. Hedgerow Farms, Winters, California, was contracted to propagate the new native grass sod mix. Starting in October 2005, each species was grown in monoculture to evaluate individual sod-forming characteristics. These five species were also grown together, i.e. MSU Native Grass SodHedgerow, to assess the overall quality and success of a mixed native grass sod. Cover crop species included annual hairgrass (Deschampsia elongatum), and Quickguard $\AA$ which was a sterile annual cross between wheat and cereal rye.

The Brentwood silty clay loam soil type dominated most of the landscape at Hedgerow Farms. Soil textural classes were clay and silty clay; the rock content, i.e. particles greater than $2 \mathrm{~mm}$ diameter, was less than $1 \%$. The soil had adequate plant-available levels of phosphorus and potassium, but nitrogen levels were low. During January 2006, plant development in the seeded area was evaluated by collecting density and canopy cover data on native grass, cover crop, and weed species. Ten Daubenmire frames were randomly dropped on the native grass monoculture, on the monoculture/cover crop mix, and on the MSU Native Grass Sod-Hedgerow species mix. Soil cover was measured using line-intercept sampling.A mark was placed every $30 \mathrm{~cm}$, and the type of soil cover was recorded, resulting in 50 data collection points. Observational data were collected on root density for each grass species. Root density in the top $6 \mathrm{~cm}$ verses the top $30 \mathrm{~cm}$ of soil was also observed. Cut sod was moved to a nearby location on Hedgerow Farms for propagation and observation.

Native Species Monoculture And Monoculture/Cover Crop Findings

Measurements of native grass monocultures and monoculture/cover crop provided the following findings pertaining to sod development and harvesting:

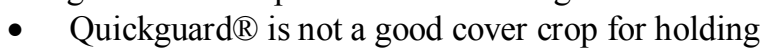
sod together because root development is too deep.

- Hairgrass provided good binding of the soil and improved the ability to cut, roll and move native sod. If used, hairgrass should be given ample irrigation prior to sod cutting to ensure it is well established.

- For most native grass species, density and/or cover decreased when seeded in conjunction with a cover crop.

- Sandberg's bluegrass was the native species with the most roots in the upper soil profile and had the best sod forming traits regarding cutting, rolling and moving.

The cover-crop Quickguard $\AA$ did not survive well for the first month in transplanted grass sod, and negatively impacted survival of the native grass species (Figure 5.8). Overall, Quickquard $\circledast$ appeared to out-compete native grasses, and the one meter tall plant did not provide good cover. Hairgrass did not appear to compete with natives, provided good cover between bunches of native grass, and provided good root binding traits that held sod together while transplanting.

The MSU Native Grass Sod-Hedgerow propagation area was evaluated in May 2006. Each of the five species seeded were present and were healthy. Seeded native grass species had a mean canopy cover of $80 \%$ and ranged from $60 \%$ in the thinnest areas to $100 \%$ in the densest areas. There were a few unwanted grasses and broadleaf weeds which contributed to less than $5 \%$ of the canopy cover.

A plan was established to increase live basal cover and root mass of the MSU Native Grass Sod-Hedgerow propagation area. Hedgerow Farms staff were asked to increase irrigation frequency, mow grass every other week to promote root growth, apply nitrogen and phosphorus fertilizer to enhance root growth, inter-seed with red fescue (Festuca rubra) to increase sod strength, and control broadleaf weeds.

The red fescue failed to establish in the MSU Native Grass Sod-Hedgerow propagation area. Weed control was not successful and weedy annuals were producing seed. Since the MSU Native Grass Sod-Hedgerow was transplanted to the highway test area in November 2006, continued efforts to improve the sod quality in the propagation area were terminated in Spring 2007.

\section{Propagation of MSU Native Grass Sod-Delta}

Greenhouse research at MSU indicated that a sod mixture with four native grass species tended to have higher sod strength. It was determined the rhizomatous growth trait of red fescue increased sod strength when combined with other native grass species.In September 2007, Delta Bluegrass Company in Stockton, California, was contracted to propagate the MSU Native Grass SodDelta. Highway Reclamation Using Native Grass Sod for SedimenTo minimize weed and fungus problems, the sod production field was fumigated prior to seeding the native grasses. A fumigation application of methyl bromide 448 kg/ha (400 pounds/acre) occurred on August 25, 2007. While the grass was germinating, the MSU Native Grass Sod-Delta propagation area was watered approximately 90 minutes per day. Following germination, the area was irrigated as needed to keep the soil moist.

A composite soil sample from the $0-15 \mathrm{~cm}$ depth increment was collected and analyzed at Energy Laboratories, Helena, Montana. The soil had adequate plant-available levels of nitrogen, phosphorus and potassium. In December 2007, ten weeks after seeding, the MSU Native Grass Sod-Delta propagation area was evaluated at the Delta Bluegrass Company farm. All seeded species were present in the native grass sod which had a total canopy cover of approximately $90 \%$. 


\section{CALifornia GRASSLAND HighWAY DEMONSTRATION AREA}

Within the California Grassland Ecoregion, a test plot area was selected approximately $10 \mathrm{~km}$ south of Sacramento, California, at the intersection of Mack Road and Highway 99. A highway fill-steep slope and a drainage swale test area were delineated at this location.

The highway fill-steep slope had a southern exposure $\left(172^{\circ}\right)$ and a slope gradient of $41 \%$. The slope was largely devoid of vegetation and weeds were present on the perimeter of the planned test plot area. A variable thickness $(0-10 \mathrm{~cm})$ of woodchips was present across the surface.

Side slopes forming the drainage swale had a $5 \%$ gradient and the channel bottom had a 3\% gradient that conveyed water off the site. The swale area had a western exposure $\left(258^{\circ}\right)$.

\section{A. Precipitation Record during the Investigation Period}

During the period of this study, September 2006 to August 2008, precipitation was $27 \%$ below the historical average of $92.4 \mathrm{~cm}$ (Figure 1). During the last four months of 2006 , precipitation was $32 \%$ below the historical average of $16.2 \mathrm{~cm}$. During 2007, precipitation was $29 \%$ below the historical average of $46.2 \mathrm{~cm}$. During the first eight months of 2008, precipitation was $20 \%$ below the historical average of $29.9 \mathrm{~cm}$.

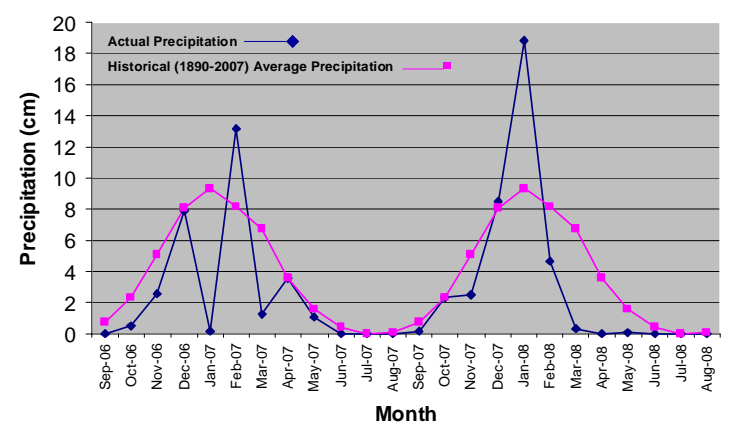

Figure 1 Actual precipitation received during the period of this native grass sod investigation compared to historical average precipitation.

\section{B. Experimental Design-Treatment Implementation}

The experimental design at the Mack Road location was implemented during an 18 month period from November 2006 to May 2008 (Figure 5.17). Each test plot treatment was three meters wide and ten meters long. With one exception, each treatment was replicated three times on the steep slope and three times on the drainage swale. The Delta Fescue Sod treatment was instituted on the drainage swale and steep slope areas, but was not replicated.

In April 2005, Restoration Resources sprayed the entire steep slope and drainage swale test areas with Roundup $^{\circledR}$ at a rate of $4673 \mathrm{~cm}^{3} /$ ha (2 quarts/acre) in order to kill all actively growing plant material. During the period May 2005 through December 2007, weed growth was managed using a garden hoe and localized applications of Roundup ${ }^{\circledR}$. Exposed soil areas adjacent to hydroseed and sod test plots were maintained in this manner. Weeds were not removed if they were growing within the hydroseed- and sod-treated areas.

In October 2006, Restoration Resources was contracted to scrape approximately $12 \mathrm{~cm}$ of woodchip mulch off the steep slope area until mineral soil was exposed. Both the drainage swale and the steep slope were tilled to a depth of $15 \mathrm{~cm}$. Test plots in the drainage swale and steep slope area, where sod was going to be placed, were fertilized with $70 \mathrm{~kg} / \mathrm{ha}$ of $15-30-0$ grade fertilizer. Fertilizer was raked into the soil. Fertilizer consisted of $11.7 \%$ ammonia nitrogen, $3.3 \%$ urea nitrogen, and $30 \% \mathrm{P}_{2} \mathrm{O}_{5}$. Control test plots received fertilizer in concert with the standard Caltrans Hydroseed-mulch procedure.

Caltrans staff specified that the demonstration area should not be mowed since this procedure could influence plant species presence. However, in December 2006 a highway maintenance crew inadvertently mowed the test plot area. This meant that the MSU Native GrassHedgerow, Caltrans Hydroseed-Mulch treatment, and Delta Fescue Sod were mowed once. Since the MSU Native Grass Sod-Delta was not transplanted until May 2008 , it was never mowed.

A fence surrounding the test plot area was not approved since it could pose a safety problem. Alternately, four survey posts were installed at the corners of the drainage swale and steep slope plot areas. Caltrans maintenance crew members were advised to not disturb these two staked areas during routine highway maintenance.

In November 2006, the standard Caltrans Hydroseedmulch procedure was instituted which was the control treatment (Figure 2). Caltrans Special Provisions for hydroseeding (erosion control type D) were followed for control plots. This treatment conformed to the provisions in Section 20-3, "Erosion Control," of the Standard Specifications. According to the provisions, the seed mix consisted of the following species: Spanish clover (Lotus pershianus), blue wildrye (Elymus glaucus), meadow barley (Hordeum brachyantherum), tidy tips (Layia platyglossa), creeping wildrye (Leymus triticoides), and purple needlegrass (Nassella pulchra).

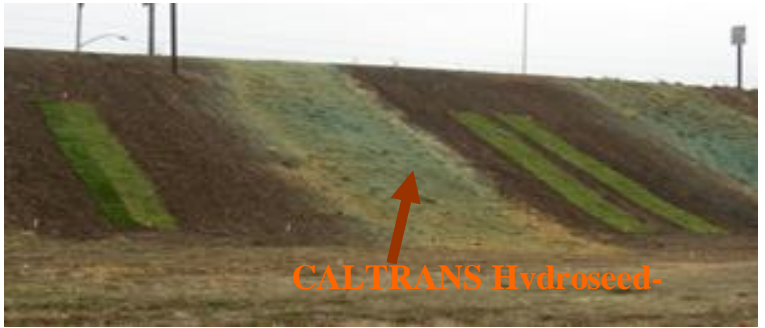

Figure 2 View of the Caltrans Hydroseed treatment on the highway fill-steep slope in November 2006.

Fertilizer was incorporated into the hydroseed mixture and consisted of $6-7 \%$ nitrogen, $2-3 \%$ phosphoric acid and $3-4 \%$ water soluble potash. Erosion control material was applied in a separate application using the following sequence:

1) the seed mix was applied with hydroseeding equipment within 60 minutes after the seed has been added to the slurry, 
2) straw was applied at the rate of four tons per hectare $\left(0.07 \mathrm{lbs} / \mathrm{ft}^{2}\right)$, and

3) fiber, fertilizer and stabilizing emulsion were applied with the hydro-seeding equipment.

Samples of straw per square foot were taken on November 13, 2006, dried at MSU and weighed to measure the actual rate of straw applied. The rate was 11.6 tons/ha $\left(0.20 \mathrm{lbs} / \mathrm{ft}^{2}\right)$.

In November 2006, the MSU Native Grass SodHedgerow was harvested at $\mathrm{H}$ edgerow Farms and transplanted to the highway test area. Sod in the propagation area developed a weak root matrix that impaired harvest at the farm. Therefore, the quantity of MSU Native Grass Sod-Hedgerow harvested was sufficient to cover half of each test plot on the steep slope and drainage swale.

Prior to cutting the sod, the grass was rolled with an industrial roller. This technique leveled the cutting surface and firmed the soil to help hold the sod together while transplanting. The sod, composed of five native grass species, was cut to the $6 \mathrm{~cm}$ depth using a $45 \mathrm{~cm}$ wide self-propelled sod cutter (Figure 3 ). Because the cut sod did not hold together when rolling, it was further cut into $45 \mathrm{~cm} \times 50 \mathrm{~cm}$ pieces then lifted and placed onto wood boards using metal scoop shovels. Stacking sod loaded boards in the trailer minimized vibration during transport (Figure 4).
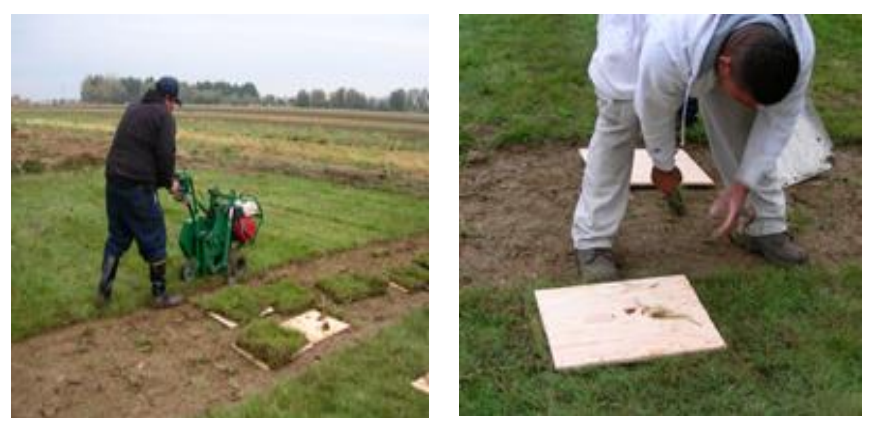

Figure 3 Cutting MSU Native Grass Sod-Hedgerow at Hedgerow Farms in November 2006 and placement of sod slabs on transport boards.
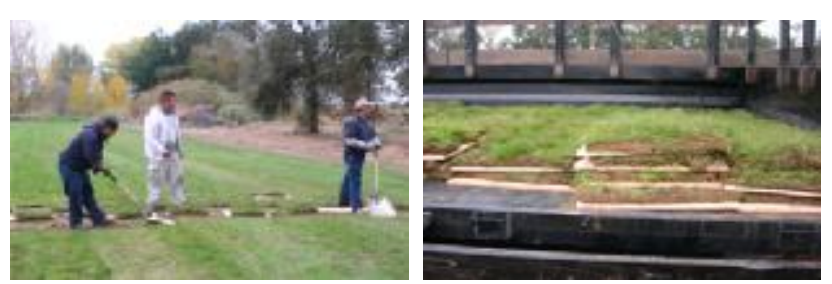

Figure 4 Lifting the cut sod onto boards using a shovel (left photo) and stacking the boards for transport on a trailer bed (right photo).

At the Mack Road highway test area, the MSU Native Grass Sod-Hedgerow was slid off boards and placed in a $1 \mathrm{~m} \times 10 \mathrm{~m}$ long strip on each plot. While handling the sod, some sod broke into smaller pieces. When transplanted, the sod was pieced together so no gaps were present across the surface. Because the sod did not form a binding root-mass, it could not be stapled into place. Within 24 hours of transplanting, the MSU Native Grass
Sod-Hedgerow was irrigated with $3 \mathrm{~cm}$ of water using a Caltrans water truck.

In November 2006, a $0.6 \mathrm{~m}$ wide by $10 \mathrm{~m}$ long strip of the Delta Fescue Sod was placed on the highway steep slope and drainage swale test areas. This fescue mix was composed of $30 \%$ hard fescue (Festuca longifolia, nonnative), 30\% sheep fescue (Festuca ovina, non-native), $20 \%$ creeping red fescue (Festuca rubra, native), and 20\% chewings fescue (Festuca rubra commutate, non-native). This sod product was designed, propagated, and installed at the highway test area by the Delta Bluegrass Company.

In May 2008, the MSU Native Grass Sod-Delta was harvested at the Delta Bluegrass Company farm and transplanted to the highway test area. In order to enhance sod root-soil contact, a $4 \mathrm{~cm}$ thickness of a compost material termed "Topsoil Blend" was applied between the sod and underlying natural soil. This material had a $\mathrm{pH}$ suitable for plant growth, very high content of organic matter, and high plant available nitrogen, phosphorus, and potassium . The Topsoil Blend had a very high soluble salt content $(5.9 \mathrm{dS} / \mathrm{m})$, which may have impaired root development.

Based on the study design, the plan was to transplant sod to the highway demonstration area in late fall to take advantage of the October through March rainy season. Consequently supplemental irrigation was not planned. However, due to contractor limitations, the MSU Native Grass Sod-Delta was transplanted on May 7, 2008. To ensure that the MSU Native Grass Sod-Delta survived transplanting during unusually high temperatures in May 2008 , and through the hot and dry summer months of 2008, a temporary sprinkler irrigation system was installed immediately after sod installation at the Mack Road demonstration area. UV-resistant PVC pipe was installed on grade and multiple sprinkler heads were elevated $30 \mathrm{~cm}$ from grade to enhance water coverage. A Caltrans water well located in a pump house approximately $100 \mathrm{~m}$ from the test plots provided irrigation water. It was estimated that the water application rate was $5.1 \mathrm{~cm} / \mathrm{hr}$.

Analysis of the irrigation water indicated it was good quality with a low salt content, low sodic hazard, low nitrogen level, and suitable $\mathrm{pH}($ Table 1$)$.

Table 1 Analysis of water used to irrigate test plots at the Mack Road site.

\begin{tabular}{|c|c|}
\hline \hline Analyte & Lab Analysis \\
\hline Specific Conductance & $0.15 \mathrm{dS} / \mathrm{m}$ \\
\hline Nitrate-Nitrogen & Not Detected \\
\hline $\mathrm{pH}$ & 8.1 \\
\hline Sodium Adsorption Ratio & 0.4 \\
\hline \hline
\end{tabular}

Following installation of the MSU Native Grass SodDelta, it was sprinkler irrigated four times per day for 14 days, then reduced to three times per day for 14 days, and finally to once a day. Irrigation cycles began at 1:00 am (long cycle), 7:00 am, 1:00 pm, and 7:00 pm. The long irrigation cycle was set for 30 minutes on the swale and 45 minutes on the slope. Other irrigation cycles were set for 10 minutes on the swale and 30 minutes on the slope. When the water schedule was reduced to three times per day, the 1:00 pm cycle was eliminated. After four weeks, 
the sod was watered once per day at 1:00 am and all irrigation cycles were 10 minutes long.

\section{NATIVE GRASS ESTABLISHMENT WITH SOD AND HYDROSEED}

Native grass establishment was monitored during a 20 month period following implementation of sod and hydroseed-mulch treatments at the Mack Road steep slope and drainage swale test area. The sequence of vegetation monitoring events was as follows:

- November 2006 - Immediately following installation of the Caltrans Hydroseed-mulch treatment and transplanting the MSU Native Grass Sod-Hedgerow and the Delta Fescue Sod, selected plant measurement were completed. During November 2006 to March 2007 a test was completed to determine the origin of weeds in test plot areas.

- $\quad$ May 2007 - Six months after implementing the Caltrans Hydroseed-mulch treatment and transplanting the MSU Native Grass SodHedgerow and the Delta Fescue Sod; plant measurements were completed at the Mack Road test area.

- May 2008 - Eighteen months after implementing the Caltrans Hydroseed-mulch treatment and transplanting the MSU Native Grass Sod-Hedgerow and the Delta Fescue Sod; plant measurements were completed at the Mack Road test area.

- $\quad$ August 2008 - Three months after implementing the MSU Native Grass Sod-Delta treatment; plant measurements on this treatment were made at the Mack Road test area.

\section{Summary AND Key FindingS}

The purpose of this research was to develop and demonstrate native grass sod for control of sediment loss from land disturbances associated with the California highway system. Two types of native grass sod were developed at two different nurseries in the California
Grassland Ecoregion near Sacramento. The first, MSU Native Grass Sod-Hedgerow, was composed of five species: creeping wildrye, purple needlegrass, Sandberg's bluegrass, California meadow barley, and squirrel tail. The second, MSU Native Grass Sod-Delta, was developed 18 months after the Hedgerow sod and was composed of two species common to the Hedgerow mix, purple needlegrass and California meadow barley and two new species California brome and red fescue.

\section{ACKNOWLEDGMENT}

This work was financially supported by Science and technology project of Hubei province transportation hall(2013-731-1-7)

\section{REFERENCES}

[1] Stohlgren, T. J., D. T. Barnett and J. Kartesz. 2003. The Rich Get Richer: Patterns of Plant Invasions in the United States. Frontiers in Ecology and the Environment 1:11-14.

[2] Tilman, D. 1996. Biodiversity: population versus ecosystem stability. Ecology, 77:350-363.

[3] Hanson, J. 2008. Personal communication with Caltrans Landscape Construction. California Department of Transportation, Sacramento. December.

[4] P \& D Environmental. 2004. Caltrans native grass evaluation pilot program (Comprehensive Report and multiple reports on specific California counties). Prepared by P\& D Environmental,Orange County, CA for the Caltrans Landscape Architecture Program, Sacramento, CA.

[5] Stott, L. V. 2007. Determining the suitability of native grasses for highway revegetation sod.Masters Thesis, Montana State University, Bozeman, Montana.

[6] Stohlgren, T. J., D. T. Barnett and J. Kartesz. 2003. The Rich Get Richer: Patterns of Plant Invasions in the United States. Frontiers in Ecology and the Environment 1:11-14.

[7] Tilman, D. 1996. Biodiversity: population versus ecosystem stability. Ecology, 77:350-363.

[8] USDA, NRCS (United States Department of Agriculture, Natural Resource and Conservation Service). 2007. The PLANTS Database. URL http://plants.usda.gov [accessed on 3 May 2007).

[9] Wardle, D. A. 2002. The regulation and function of biological diversity. In S. A. Levin and H. S. Horn, editors. Communities and ecosystems: linking the aboveground and belowground components. Princeton University Press, New Jersey.

[10] Western Regional Climate Center. URL http://www.wrcc.dri.edu/Climsum.html [accessed on 3 May 2007] 